HRVOJE KEKEZ

https://orcid.org/0000-0002-9107-0236

Department of History

of the Catholic University of Croatia, Zagreb

\title{
LECH'S SUPPOSED ORIGINS IN CROATIA: REGARDING THE IDENTIFICATION OF THE RIVERS HUY AND KRUPA IN THE WORKS OF JAN DŁUGOSZ AND MACIEJ OF MIECHÓW*
}

\begin{abstract}
The present article is a further contribution to the debate on the famous late medieval and early Renaissance narrative of the legendary origins of the Poles. The paper focuses on the legendary castle of 'Psary' - the 'ancestral home' of Prince Lech, that is on the geographical information given by chroniclers Jan Długosz and Maciej of Miechów in their writings. The author dismisses the identification of 'Psary' with Krapina or Pharos (Starigrad on the island of Hvar), arguing that 'Psary' was the medieval Minor Pset most likely located on top of Pušačko Hill (Pušačko brdo) in the vicinity of the late medieval castle Krupa (present-day Bosanska Krupa in Bosnia and Herzegovina).

Ke y w or ds: Lech, Croatia, Psary, Krupa, the River Una, legendary origins of the Poles, origo gentis, Renaissance historiography, historical geography.
\end{abstract}

The story of how two brothers, Lech and Czech (or, depending on the source, three - along with Rus), came from the south (Pannonia) and became the forefathers of their respective nations (the Poles, Czechs and, according to some interpretations, the Russians) is probably one of the best examples of the origo gentis type of narrative often used by Renaissance authors. The purpose of these and similar stories, which were either elements of oral tradition or were composed by individuals in specific historical and social contexts, and which commonly linked the ancient mythical past with the present, was usually to associate contemporary social elites with legendary ancestors and/or gods. That is, their goal - according to

${ }^{*}$ The present study has received financial support from the Catholic University of Croatia under the project 'Perception of Croatian, Slavonian and Dalmatian Elites in the Late Medieval and Early Modern Period' (HKS-2017-6). 
Anthony D. Smith - was to explain not only the origins of a society, but also its historical growth and destiny, in order to strengthen the position of contemporary elites. ${ }^{1}$ Nevertheless, the very meaning of these stories was not to present real history and/or tradition, but to create a temporary identity and to strengthen it through the use of "cultural memory' by invoking a glorious and ancient past. ${ }^{2}$

Although it was Master Vincentius who at the beginning of the thirteenth century mentioned the tribe of the Lechites in his chronicle ${ }^{3}$ it was Jan from Dąbrówka who in the first half of the fifteenth century (circa 1433) briefly introduced three brothers - Lech, Czech and Rus - as the forefathers of their respective nations in his comments on Vincentius' work. ${ }^{4}$ In spite of the fact that in the second half of the fifteenth century the famous chronicler Jan Długosz (Ioannes Dlugossious) omitted the third brother (Rus) from his narrative, he endowed the story with greater historical semblance by giving Lech the necessary attributes of a historical character. ${ }^{5}$ Długosz wrote that Lech was the primogenitor of the Poles, while Czech was the forefather of the Czech nation, and that the two brothers were originally from Pannonia, that is from the area at the meeting point of Dalmacia Sermiensis (that is, the medieval Duchy of Srijem), Slavonia, Croatia and Bosnia. ${ }^{6}$ Moreover, Długosz indicated the castle of 'Psary' as Lech's place of origin, and gave a rather precise description of its location. Namely, he wrote that the castle of 'Psary' was situated on a cliff high above the river Huj, at the border of Slavonia and Croatia. ${ }^{7}$

Being familiar with Długosz's writings, and after personally visiting the Balkans in order to verify the geographical information given by him, ${ }^{8}$

${ }^{1}$ Anthony D. Smith, The Ethnic Origins of Nations, Oxford, 1986, p. 24.

${ }^{2}$ Sebastian Brather, 'Ethnische Identitäten als Konstrukte der frühgeschichtlichen Archäologie’, Germania, 78, 2000, pp. 139-77 (pp. 152-53).

${ }^{3}$ Magistri Vincentii dicti Kadłubek Chronica Polonorum, ed. Marian Plezia, Cracow, 1994, MPH s.n., vol. 11.

4 'Polonia eciam Lechia appellatur, aqua Lechite suum sumpserunt vocabulum, que a Lech seniore filio Panonis nomen sibi usurpavit. Pano enim legitur tres filios habuisse: Lech, Rus et Chech', Ioannes de Dąbrówka, Commentum in Chronicam Polonorum magistri Vincentii dicti Kadłubek, ed. Marian Zwiercan, Cracow, 2008, p. 6, MPH s.n., vol. 14.

${ }^{5}$ Aleksander Małecki, "Croatian "Psary" Versus Dalmatian "Pharos" in the Legendary Beginnings of Poland', Sensus Historiae, 10, 2013, pp. 9-20 (p. 11).

6 'Duo itaque filii Jani nepotis Japeth, Lach et Czech, quibus Dalmacia Sermiensis, Slawonia, Carwacia et Boszna contingerant', Ioannis Dlugossi Annales seu Cronicoe incliti Regni Polonice. Liber 1/2, ed. Wanda Semkowicz-Zaremba, Warsaw, 1964, p. 70.

7 'et ex castro Psary in altissima rupe, quod fluvius Huy Slawoniam Carwaciamque disterminans abluit', Ioannis Dlugossi Annales, p. 70.

${ }^{8}$ Małecki, 'Croatian "Psary”', p. 12, n. 16. 
Maciej of Miechów wrote his Tractatus de duabus Sarmatiis, which became widely known in contemporary Europe. In his work, Maciej of Miechów confirmed the existence of Lech's castle. He wrote that it was located on the river Krupa, and that its original name was still preserved among the local Slavic people. ${ }^{9}$ At first glance it would seem that Maciej of Miechów replaced the name of the river 'Huj' with that of 'Krupa', and by doing so introduced confusion to the geographical information about Lech's 'ancestral home' ${ }^{10}$

The subsequent writings of sixteenth-century chroniclers only furthered the confusion. For example, Marcin Kromer (1555) omitted the name of the river (Krupa) and replaced it with two towns: Krapina and Psary. The poet Clemens Ianicius (1563) morphed 'Psary' into 'Pharijs', which led later historians to assume that Lech's hometown was actually the Roman city of Pharos (present-day Starigrad) on the island of Hvar in contemporary Croatia. ${ }^{11}$ In his excellent recently published work, Aleksander Małecki successfully disproved the possibility that Długosz's 'Psary' is actually Pharos, ${ }^{12}$ and wrote that he must 'helplessly conclude that attempts at finding the geographical location of Dlugossius' Psary, even an approximate one, seem futile'. ${ }^{13}$

Although the mythical ancestry of the Poles and the legend of Lech's hometown did not come within the focus of modern Croatian historiography, which started to develop in the mid-nineteenth century, they have sometimes been used to explain the origins of the Slavic peoples. In 1826, Ljudevit Gaj - one of the leaders of the Croatian national movement of the mid-nineteenth century, ${ }^{14}$ put forward the

9 'villa usque in hodiernum diem cum suo nomine Psari permanet ad fluenta Krupæ, plures iubaiones et colonos nostro evo etiam linguagii Slauonici habens', Mathias de Miechow, Tractatus de duabus Sarmatijs Asiana: \& Europiana \& de contentis in eis, Cracow, 1517, p. Cij.

${ }^{10}$ Małecki, 'Croatian “Psary"', p. 12.

${ }^{11}$ See in more details: ibid., pp. 12-15.

12 Ibid., p. 12.

${ }^{13}$ Ibid., p. 20.

${ }^{14}$ Born in Krapina, Ljudevit Gaj (1809-1872) became one of the most prominent leaders and ideologists of the Croatian national movement in the mid-nineteenth century. The main goals of this political and social grouping, commonly known as Ilirski narodni preporod (the Illyrian National Rebirth), were concerned with securing the political autonomy of historically Croatian lands (Croatia, Dalmatia and Slavonia) within Habsburg Monarchy, as well as strengthening the cultural, social and economic identity of the Croatian nation. Gaj was also a historian, a man of letters, and a poet, and he went on to publish a copious body of writings - scholarly (mostly historical) works, political literature and also novels. On Ljudevit Gaj and the Croatian national movement of the mid-nineteenth century, see: Temelji moderne Hrvatske: Hrvatske zemlje u 'dugom' 19. stoljeću, ed. Vlasta Švoger and Jasna Turkalj, Zagreb, 2016. 
version whereby Lech, the forefather of the modern Polish nation, had come from Krapina. Gaj presented this as a folk story which he had heard from the inhabitants of Krapina. ${ }^{15}$ In 1890, Radoslav Lopašić, a Croatian historian from the late nineteenth century, ${ }^{16}$ dismissed it as unlikely that Długosz's 'Psary' was the medieval castle of Krapina, however without giving a detailed explanation of his opinion. ${ }^{17}$ And indeed, Długosz had clearly stated that 'Psary' was situated on the border of Slavonia and Croatia, which would dismiss the possibility of 'Psary' being Krapina, because in medieval slavonia the stronghold of Krapina was located near to the border of the German Empire, that is the southern Steiermark. ${ }^{18} \mathrm{Fi}$ nally, in 1925, Ferdo Šišić, a professional historian and Professor of Medieval History at the University of Zagreb, concluded in his book on Croatian lands in the early Middle Ages that Gaj had not recorded an actual local tradition according to which Lech had come from Krapina, but that he had most likely chanced upon an entry to this effect in some older chronicles (possibly Polish) and only presented it as such, ${ }^{19}$ thus acting in line with the tenets of the Croatian offshoot of the Romantic and national revival which gained momentum among the Slavic peoples in the first half of the nineteenth century. Indeed, it is very probable that Gaj had read the Memoria regum et banorum Regnorum Dalmatioe, Croatioe et Sclavonice, a chronicle written in Latin by Juraj (George) Rattkay, the canon of the Chapter of Zagreb, ${ }^{20}$ in the mid-seventeenth century and published in 1652. Through his record Rattkay intended to present the origins and

${ }^{15}$ Ljudevit Gaj, Die Schlösser bei Krapina, Karlovac, 1826, pp. 14-22.

${ }^{16}$ Radoslav Lopašić (1835-1893) was a Croatian historian who wrote a significant number of studies and more than fifteen books devoted primarily to Croatian medieval and early modern history. He also edited several editions of early modern historical sources, the most important of which were Spomenici Hrvatske krajine, 3 vols (Zagreb, 1884-89). On Radoslav Lopašić, see: Tadija Smičiklas, Radoslav Lopašić: Nekrolog, Zagreb, 1895.

${ }^{17}$ Radoslav Lopašić, Bihać i Bihaćka Krajina: Mjestopisne i poviestne crtice, Zagreb, 1890, pp. 200-01.

18 On the term 'Slavonia' in the Middle Ages, see: Tomislav Bali, Slavonski meandar: Prostor i pojam Slavonije u XIII. stoljeću, Zagreb, 2014.

${ }^{19}$ Ferdo Šišić, Povijest Hrvata u vrijeme narodnih vladara, Zagreb, 1925, pp. 182-83. It should be added that when he published his paper on the topic, Gaj was only sixteen and heavily influenced by the Romantic and national movements that were gaining popularity in contemporary Europe.

${ }^{20}$ Juraj Rattkay (1612-1666) was the canon of the Chapter of Zagreb and a professional historian whose Memoria regum et banorum Regnorum Dalmatioe, Croatice et Sclavonice is considered to be first systematic synthesis of Croatian history. On the life and work of Juraj Rattkay, see: Sándor Bene, 'Ideološke koncepcije o staleškoj državi zagrebačkoga kanonika', in Juraj Rattkay, Spomen na kraljeve i banove Kraljevstva Dalmacije, Hrvatske i Slavonije, transl. Zrinka Blažević et. al., Zagreb, 2001, pp. 4-103. 
history of Croats in accordance with the principles of the origo gentis genre, and he duly wrote down that Lech and Czech were originally from Krapina. More interestingly still, he noted that this story was well known to Polish and Czech historians and writers, naming among them Cardinal Stanisław Hozjusz (1504-1579) and his Confessio fidei catholicee christiana. ${ }^{21}$ Although in this particular work Cardinal Hozjusz did not refer to the legend of the brothers Lech and Czech, it is worth observing that Rattkay's chronicle was known to Polish authors; this should not come as a surprise, for Rattkay studied in Graz and Vienna, and often visited numerous towns in Hungary, such as Györ and Pozsony (present-day Bratislava), Germany and Bohemia. ${ }^{22}$ Therefore, it is likely that he was familiar with the writings of Marcin Kromer, who in 1555 had been the first to introduce Krapina to the narrative of the brothers Lech and Czech. ${ }^{23}$ If this had indeed been the case, then the introduction of Krapina to that narrative is a good example of the 'circular movement' of a historical narrative - from Poland to Croatia and back.

This leads us to the following important question - is it at all possible to find the castle of 'Psary', or is this as futile an enterprise as Małecki purported? The author of the present paper intends to undertake his own attempt, however without any presumption of arriving at a final and definitive answer.

In order to do so, one must return to Długosz's writings and the geographical information which he supplied. As has already been mentioned, Długosz gave Lech's place of origin as the castle of 'Psary', situated on a high cliff over the River Huj, on the border of Slavonia and Croatia. ${ }^{24}$ This provides us with three items of geographical data - the name of the castle (Psary), the name of the river (Huj), and the location of the castle (on the border of Slavonia and Croatia).

There can be no doubt that the river (Huj) mentioned in Długosz's writings is the modern-day Una, situated along the border between the Republic of Croatia and the Republic of Bosnia and Herzegovina. This river was often mentioned in various medieval sources (mostly charters) from the beginning of the thirteenth century up to the end of the Middle Ages, and its name was recorded in several versions (Un, Hun, Wn), the use

${ }^{21}$ Rattkay, Spomen na kraljeve, p. 138.

${ }^{22}$ Bene, 'Ideološke koncepcije'.

23 'Lechum enim \& Ziechum fratres, principes viros, apud Crapinam \& Psaros degentes', Martinus Cromerius, De origine et rebus gestis Polonorum libri XXX, Basel, 1555, p. 20; Małecki, 'Croatian "Psary”', p. 13.

24 'et ex castro Psary in altissima rupe, quod fluvius Huy Slawoniam Carwaciamque disterminans abluit', Ioannis Dlugossi Annales, p. 70. 
of which depended chiefly on the knowledge and skills of the writer. ${ }^{25}$ The valley of the River Una was one of the most important traffic routes leading from the Dalmatian coast towards Slavonia and Hungary (Via Colomani regis) during the Middle Ages, ${ }^{26}$ until the late fifteenth and the beginning of the sixteenth century, when it became very dangerous due to Ottoman raids and their subsequent conquest of the area. ${ }^{27}$

Furthermore, the castle of 'Psary' mentioned by Długosz was most likely the political, economic and social center of a medieval Croatian county (Cro. županija, Lat. comitatus, Hun. megye) called Pset, which is mentioned in sources from the end of the twelfth century until the beginning of the sixteenth century. The county of Pset was situated north of Knin and Vrlika, in the lands between the River Unac and the upper Una valley ${ }^{28}$ The eastern border of this administrative unit was the River Sana, while its northeastern boundary was the mountain of Grmeč. Hence, the medieval county of Pset was mostly situated in the karst fields of Bilaj and Petrovac (Bilajsko-petrovačko polje, presently in Bosnia and Herzegovina), ${ }^{29}$ and it was the northernmost medieval Croatian province, situated at the country's border with Slavonia (Fig. 1), ${ }^{30}$ which fits the description given by Długosz. ${ }^{31}$

The county of Pset was mentioned as early as in the middle of the tenth century by the Byzantine Emperor Constantine VII Porphyrogenitus in his well-known work De Administrando Imperio. In it, he listed Pset

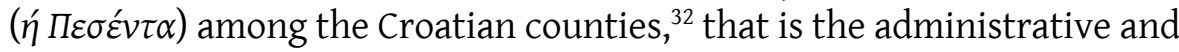
territorial units of the Kingdom of Croatia. Each such territory usually had a stronghold which functioned as the seat of the local count (Cro.

${ }^{25}$ For example: 1240 - 'iuxta Vn', Codex diplomaticus Regni Croatice, Dalmatice et Slavonice, ed. Tade Smičiklas, 18 vols, Zagreb, 1904-90 (hereafter Smičiklas, Codex), vol. 4, 1906, p. 121; 1249 - 'in fluvium Wn', ibid., p. 411; 1256 - 'fluvium qui nominatur Vna', Smičiklas, Codex, vol. 5, 1907, p. 9; 1263 - 'vtraque parte Hun', ibid., p. 278; 1328 - 'iuxta fluvium Wn', Smičiklas, Codex, vol. 9, 1911, p. 415.

${ }^{26}$ On major roads in medieval Croatian lands and their technical condition, see: Lovorka Čoralić, Put, putnici i putovanja: Ceste i putovi u srednjovjekovnim hrvatskim zemljama, Zagreb, 1997.

${ }^{27}$ On individual Ottoman raids and the Ottoman conquest of the lands around the valley of the River Una, see: Ive Mažuran, Hrvati i Osmansko Carstvo, Zagreb, 1998, pp. 34-151.

${ }^{28}$ On the medieval Pset County see: Vjekoslav Klaić, 'Županija Pset (Pesenta) i pleme Kolunić', Vjesnik Hrvatskog arheološkog društva NS, vol. 15, 1928, pp. 1-12.

${ }^{29}$ Ibid., p. 1.

30 Borislav Grgin, 'Županije u razvijenom i kasnom srednjem vijeku', in Hrvatske županije kroz stoljeća, ed. Ivo Goldstein, Zagreb, 1996, pp. 21-38 (p. 26).

31 'Slawoniam Carwaciamque disterminans', Ioannis Dlugossi Annales, p. 70.

${ }^{32}$ Nada Klaić, Izvori za hrvatsku povijest do 1526. godine, Zagreb, 1972, p. 41. 
župan, Lat. comes), who held political, military, juridical and fiscal authority in the name of the ruler - the king..$^{33}$

Later, the County of Pset was recorded in charters. In 1185, at the Metropolitan Synod in Split, the lands of this administrative unit became an integral part of the Diocese of Knin. ${ }^{34}$ Its first known count was Dennis I Babonić, recorded as such in $1266 .{ }^{35}$ In the second half of the thirteenth century, not one but two counties of Pset (Minor and Major Pset) are mentioned in sources, ${ }^{36}$ with two centres. The seat of Major Pset was most likely the castle whose ruins are still visible on the Grmeč Mountain, while the political and economic centre of Minor Pset was in all probability Krupa castle, situated in the canyon of the River Una. ${ }^{37}$

In the same period, the noble Babonić family gradually assumed political power over these lands. Dennis I became the first in the line to assume the title of count of Pset, in $1266,{ }^{38}$ while a few years later (in 1280) the county was granted to the family in hereditary possession. ${ }^{39}$ During the Babonić family's period of rule over the province, the castle of Kru$\mathrm{pa}^{40}$ evolved into the political and economic centre of the middle Una valley. This fortress, first mentioned in $1343,{ }^{41}$ was situated on a small hill at the widening of the River Una canyon, just above the mouth of the stream known as Krupnica (present-day Krušnica), from which it received its name (Fig. 4). ${ }^{42}$ In later years, until 1565, when it was conquered by the Ottomans, the castle of Krupa would often change hands, but it was always recorded in sources as 'Krupa' (Crupa, Cruppa, Krupn). ${ }^{43}$

It was Lopašić who had first claimed that the castle of Krupa was one and the same with Pset, arguing that until the middle of the thirteenth century Krupa had been known as Minor Pset or just Pset. ${ }^{44}$ His reasoning

${ }^{33}$ Ivan Beuc, Povijest institucija državne vlasti kraljevine Hrvatske, Slavonije i Dalmacije, Zagreb, 1985, pp. 51-56.

34 'Tiniensis episcopus habeat sedem suam in Tenin et habeat has parochias: Tenin campum, Verchreca, Pset', Smičiklas, Codex, vol. 2, 1904, p. 193.

35 'Dionisius comes de Polhana et de Peset', Smičiklas, Codex, vol. 5, p. 415.

${ }^{36} 1278$ - 'duos comitatus de Pezeth', Smičiklas, Codex, vol. 6, 1908, p. 241; 1278 'due partes duorum comitatum Pset', ibid., p. 263; 1280 - 'in utroque Pzet', ibid., p. 362.

${ }^{37}$ V. Klaić, 'Županija Pset', p. 2.

${ }^{38}$ Smičiklas, Codex, vol. 5, p. 415.

${ }^{39}$ Smičiklas, Codex, vol. 6, p. 362.

${ }^{40}$ Hrvoje Kekez, Pod znamenjem propetog lava: Povijest knezova Babonića do kraja 14. stoljeća, Zagreb, 2016, pp. 277-80.

${ }^{41}$ Milko Kos, 'Odnošaji medju goričkim grofovima i hrvatskim plemstvom u srednjem vijeku’, Vjesnik Zemaljskog arhiva, 19, 1917, pp. 208-303 (p. 298).

${ }^{42}$ Lopašić, Bihać, p. 197.

${ }^{43}$ Ibid., pp. 197-220.

${ }^{44}$ Ibid., p. 201. 
was accepted by later authors who dealt with either the history of Krupa or that of the county of Pset, the most important of these being Hamdija Kreševljaković and Vjekoslav Klaić. ${ }^{45}$

If Lopašić's assumption that Minor Pset (Pset) and Krupa were the same castle is correct, then the information given by Maciej of Miechów in 1517 becomes even more confusing, especially as he had personally visited the Balkan Peninsula in order to find Długosz's 'Psary' - the 'ancestral home' of the Poles. ${ }^{46}$ As has already been said, Maciej of Miechów wrote in his Tractatus de duabus Sarmatiis that he had visited the settlement named 'Psari' situated on the river Krupa, and that its original name had been preserved among the local slavic people until his own times. ${ }^{47}$ But in the following sentence he provided us with the key to the riddle, writing that the castle of 'Psari' (Minor Pset) was, at the time of his visit, in ruins. ${ }^{48}$

If Krupa and Minor Pset (Pset) were actually one and the same, it would have been impossible for the castle of Krupa to be in ruins in 1517, as Maciej of Miechów described it. As noted earlier, in the first half of the sixteenth century and until 1565, Krupa was a very important stronghold in the defensive anti-Ottoman line. ${ }^{49}$ Even after the Ottoman conquest, it was not abandoned but instead became a key Ottoman fortress, and in subsequent decades the Ottomans even improved its fortifications system by building several new towers (tabia). ${ }^{50}$

We should also add that there exists another piece of historical evidence describing the condition of Krupa castle in 1530, a little more than ten years after Maciej of Miechów's visit. It was written by Benedict Kuripešić (Benedict Curipeschitz), who had accompanied Josef von Lamberg and Nikolas Jurišić (Nicolas Jurischitz) on their way to the sultan's court in Istanbul in 1530. They journeyed though Croatia, Bosnia, Serbia and Bulgaria, and in following year, having returned home, Kuripešić published his travelogue. ${ }^{51}$ He recorded that he and his companions had left

${ }^{45}$ Hamdija Kreševljaković, Stari bosanski gradovi, Sarajevo, 1953, p. 35; V. Klaić, 'Županija Pset', p. 2.

${ }^{46}$ Małecki, 'Croatian "Psary”, p. 12, n. 16.

47 'villa usque in hodiernum diem cum suo nomine Psari permanet ad fluenta Krupæ, plures iubaiones et colonos nostro evo etiam linguagii Slauonici habens', Mathias de Miechow, Tractatus, p. Cij.

48 'Castrum vero demolitum, solas ruinas et fundamenta arcis demonstrat', ibid.

${ }^{49}$ Mažuran, Hrvati i Osmansko, pp. 127-52.

50 Ćiro Truhelka, Naši gradovi: Opis najljepših sredovječnih gradova Bosna i Hercegovine, Sarajevo, 1904, pp. 18-22.

${ }^{51}$ Benedict Curipeschitz, Itinerarium der Botschaftsreise des Josef von Lamberg und Niclas Jurischitz durch Bosnien, Serbien, Bulgarien nach Konstantinopel, 1530, ed. Eleonore Lamberg-Schwarzenberg, Innsbruck, 1910. 
the castle of Novigrad (present-day Todorovo in Bosnia and Herzegovina) and made their way toward the fortress and marketplace of Krupa on Sunday, 28 August $1530 .^{52}$ The following day, they left Krupa escorted by five Turks and travelled toward the nearby castle of Kamengrad, ${ }^{53}$ than already under Ottoman control.

Furthermore, in his diary Kuripešić published several drawings of the castles and settlements that he and his group had visited during their journey. Among them was the castle of Krupa (Fig. 2). On Kuripešić's drawing one can easily recognize the castle and the marketplace below it, both situated on an island formed by the River Una and the stream Krušnica (in the picture marked with the German word Ursprung, which means spring). It is also interesting to note that Kuripešić was aware that Krupa castle was located within medieval Croatia, and therefore he wrote 'Croatia' (Crabaten) on his drawing of the stronghold. It is possible that Kuripešić did so in order to emphasize the fact that it was a border castle, however still situated on Croatian territory. ${ }^{54}$

On the basis of this brief description and the drawing one may easily argue that in 1530 the castle of Krupa was still standing and that there was a marketplace below it. This condition could not have been much different from that witnessed by Maciej of Miechów less than fifteen years earlier. Consequently, Minor Pset (or Miechów's 'Psari') cannot be identified with Krupa, as Lopašić did, with his inference being accepted by later Croatian historians. It seems that Maciej of Miechów did not describe Krupa and the River Una, but a different location altogether. Indeed, in his writings he mentioned the village and castle of 'Psari' (in Psari castro ac villagio). While the village of 'Psari' was still extant, the castle of 'Psari' was abandoned at the time of his visit; its ruins (solas ruinas et fundamenta arcis) were still visible and its original name remembered by the local slavic people.

Thus, if 'Psari' (Minor Pset) was not the castle of Krupa, then where was it situated? To solve this puzzle, one has to have in mind the process that occurred during the thirteenth and fourteenth centuries in the lands of medieval Croatia, in strong connection with the growth of the economy and trade and the introduction of money throughout the medieval Realm

52 'Am Sontag, den achtundzwaizigisten Augusti von Novigrad den perg abgezogen, nachmals übet ain gepürg für Nemzitz oder Jeseriam schloß, aud der dengkhen handt ligen lassen un geen Crupa schloß und marckht khumben', Curipeschitz, Itinerarium, p. 26.

53 'Alda fünf Trggen, so noch nechten von Camengrad umb uns khumben und auf uns gewart', Curipeschitz, Itinerarium, p. 26.

${ }_{54}$ Slike iz putopisa B. Kuripešičeva u Carigrad od godine 1531, ed. Ivan Standl, Agram, 1879, [n. pag.]. 
of Saint Stephen (Kingdom of Hungary-Croatia). ${ }^{55}$ Namely, during these two centuries, as has been recorded in surviving historical accounts, it was fairly common for feudal lords to abandon their existing fortifications in order to build new ones either in river valleys or in karst fields, in any case closer to the major traffic arteries. This was due to the fact that the older sites were usually further away from such routes, as their locations had been chosen first and foremost to provide security for the inhabitants of a wider area, while the role of the newly erected strongholds was to protect traffic along these routes and facilitate the collection of tolls. Both sites would usually not be too far distant from each other (generally no more than half a mile away), while the process was customarily, but not always, accompanied by a change of place name.

There were many examples of this in medieval Croatia. For example, in the second half of the fourteenth century, the Counts of Krbava built a new castle, called Udbina, in the vicinity of the older Krbava stronghold in order to better control the karst field of Krbava. ${ }^{56}$ At approximately the same time, the Counts of Krk (later called Frankapani) decided to abandon the existing site of the Drežnik stronghold (the location of 'Metla') in order to build a new fortress by the canyon of the River Korana. ${ }^{57}$ In this instance, the new castle assumed the name of the older stronghold - Drežnik. We also find examples of this process in the valley of the River Una. Although Kostajnica was first mentioned in $1240{ }^{58}$ it was no earlier than the end of the fourteenth century that the Counts of Zrin decided to build a new castle on the island in the middle of the River Una - the Wasserburg Kostajnica - and abandon the existing site on Djed Hill on the left bank of the river. ${ }^{59}$

It may be argued that a similar process occurred with Minor Pset and Krupa. After he had visited the remains of Krupa castle, Ćiro Truhelka, who was in his time a leading Croatian expert on medieval castles, indirectly concluded that the oldest layer of the castle could be dated at the earliest

${ }^{55}$ Nada Klaić, Povijest Hrvata u razvijenom srednjem vijeku, Zagreb, 1976, pp. 272-315.

${ }^{56}$ Milan Kruhek, 'Topografija krbavske spomeničke baštine', in Krbavska bitka i njezine posljedice, ed. Dragutin Pavličević, Zagreb, 1997, pp. 99-129 (pp. 100-07).

${ }^{57}$ Idem, Drežnik Grad: Srednjovjekovno naselje i kaštel Frankopana na Korani, Rakovica, 2009, pp. 7-8.

${ }^{58}$ Smičiklas, Codex, vol. 4, pp. 121-22.

${ }^{59}$ Following extensive archeological excavations which preceded the reconstruction of Kostajnica castle, Drago Miletić concluded that the oldest layers of the structure can be dated at the earliest to the end of the fourteenth century (Drago Miletić, 'Istraživanja, konzervatorsko-restauratorski radovi i idejni projekti prezentacije s prijedlozima nove namjene staroga grada u Hrvatskoj Kostajnici', in Hrvatska Kostajnica: 1240.-2000., ed. Marija Krupić, Hrvatska Kostajnica, 2002, p. 310). 
to the beginning of the fourteenth century. ${ }^{60}$ Having this in mind, as well as the fact that the castle of Minor Pset was not mentioned in sources after the second half of the thirteenth century, one may argue that the noble Babonić family, having acquired both counties of Pset in the late thirteenth century, ${ }^{61}$ started work on a new castle closer to the major traffic route passing through the valley of the River Una - the fortress of Kru$\mathrm{pa}-$ and abandoned its former stronghold of Minor Pset. Krupa was most likely finished by the year 1343, when it was first recorded in sources. ${ }^{62}$

If this was indeed the case, one should try to locate Minor Pset, that is, the 'Psari' from the writings of Maciej of Miechów, in the vicinity of Krupa castle (which is still standing). Yet again, Maciej of Miechów left us a clue in his works. Namely, he wrote that the village and the ruins of 'Psari' castle were situated near the River Krupa (fluenta Krupce). It is very likely that Maciej of Miechów was referring to the Krušnica (Krupnica) stream, the name of which in the late Middle Ages was in all probability Krupa, while the stronghold of Krupa was probably named after it because it was built over its confluence with the River Una. If this interpretation is correct, it would be reasonable to look for Miechów's 'Psari' somewhere in the valley of the stream Krušnica. One possible location is Pušačko Hill (Pušačko brdo, $320 \mathrm{~m}$ ) in the area which even today is known as 'Puščenik' or 'Paščenik' (Fig. 3) - a toponym which preserves the memory of medieval Pset, at least according to Lopašić. ${ }^{63}$ The western slopes of Pušačko Hill are very steep and overlook the spring of the Krušnica stream, and therefore this location perfectly fits the criteria for the site of a medieval stronghold built before the thirteenth century. Nevertheless, insofar as is known to the author of the present paper, neither archaeological excavations nor even basic examinations have hitherto been conducted in the area, and so the proposition that Pušačko Hill is actually the site of Minor Pset, and therefore of Miechów's 'Psari', will remain just that - a proposition - until it is proved or disproved by archaeological research.

Finally, it should be said that the differences in the geographical information given by Długosz (the castle of 'Psary' and the river 'Huy') and Maciej of Miechów (the castle of 'Psari' and the river 'Krupa') can only be explained by the fact that each author obtained his data from different sources, and also that the 'object' of their respective writings was located at a different distance. Since Maciej of Miechów had personally visited the

\footnotetext{
${ }^{60}$ Truhelka, Naši gradovi, pp. 21-22.

${ }^{61}$ Kekez, Pod znamenjem, pp. 277-80.

${ }^{62}$ Kos, 'Odnošaji medju', p. 298.

${ }^{63}$ Lopašić, Bihać, p. 201.
} 
site, and that this visit was actually one of the goals of his journey to the Balkans, it is not surprising that his account of the location of the mythical 'ancestral home', the medieval Minor Pset, is more accurate. In contrast, it is likely that Długosz did not travel to the area of Krupa castle, ${ }^{64}$ but received his geographical data on Pset either from the Glagolitic monks from Croatia who had resided in the monastery at the Church of the Holy Cross at Kleparz in Cracow between 1390 to 1470, as has been suggested by Małecki, ${ }^{65}$ or during one of his stays in Buda. ${ }^{66}$ Therefore, it is not surprising that in his writings Długosz used a more familiar hydronym - the River Una - instead of the name of a smaller and more obscure water-course, that is the stream Krušnica (medieval Krupa).

If one were to accept the arguments presented in the present paper, the 'Psary'/'Psari' mentioned by Jan Długosz and Maciej of Miechów in their writings on the legendary origins of the Poles should be sought on Pušačko Hill in the vicinity of present-day Bosanska Krupa (Fig. 4). However, this does not solve the conundrum of the legendary origins of the Poles, since there are many other questions that Długosz's narrative leaves unanswered, for example: how exactly did he come into possession of data concerning Pset castle, why did he accept it as the 'ancestral home' of the Poles, what is the meaning of this term, and how does Pset fit into the Polish origo genits...? These and similar questions, however, do not come within the scope of the paper and should form the subject of separate research.

(Proofreading by Maciej Zakrzewski)

${ }^{64}$ There is some information suggesting that Długosz may have personally visited the area of Krupa castle in 1449. In a letter from October 1449, addressed to Marcin Król of Żurawice, Długosz wrote that he had unsuccessfully looked for him during his short stay in Buda, while returning from Rome (Analecta ad historiam renascentium in Hungaria litterarum spectantia, ed. Eugenius Abel, Budapestini et Leipzig, 1880, p. 166). Although the details of Długosz's journey from Rome to Buda are not known, it is possible that he took the road through the valley of the River Una, which - as has already been said - was one of the most common routes from the Adriatic coast to Hungary.

${ }^{65}$ Małecki, 'Croatian "Psary"', p. 19. For further information on the arrival and presence of the Glagolitic monks in that location, and on the possibility of Długosz having had contact with them, see: Julia Verholantsev, The Slavic Letters of St. Jerome: The History of the Legend and its Legacy, or, How the Translator of the Vulgate Became an Apostle of the Slavs, DeKalb, IL, 2014, pp.124-57.

${ }^{66}$ Długosz visited Buda at least once (see footnote 60). On the life of Długosz, see: The Annals of Jan Długosz: Annales seu cronico incliti regni Polonioe, ed. Maurice Michael, Charlton, 1997, pp. 603-11. 


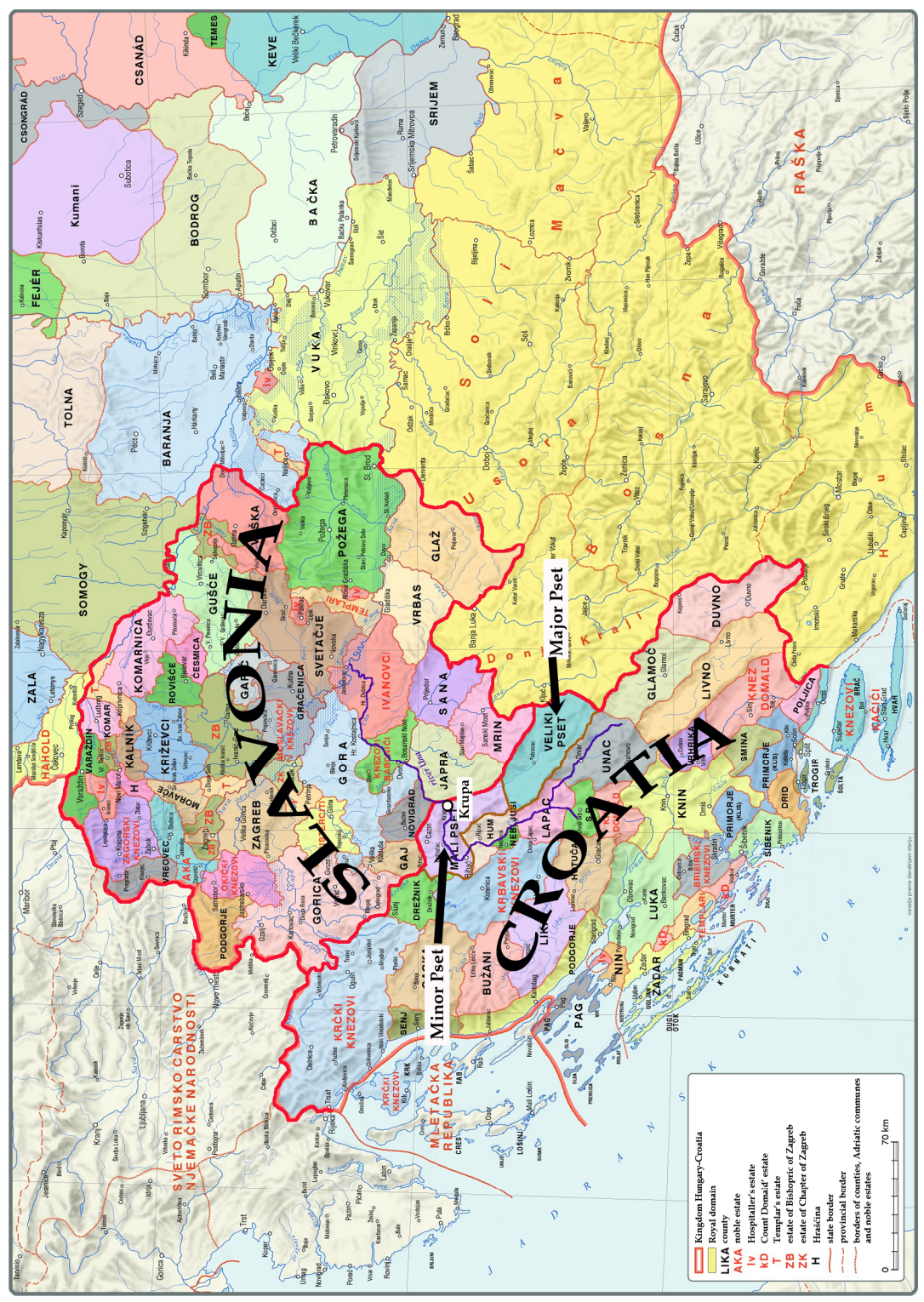

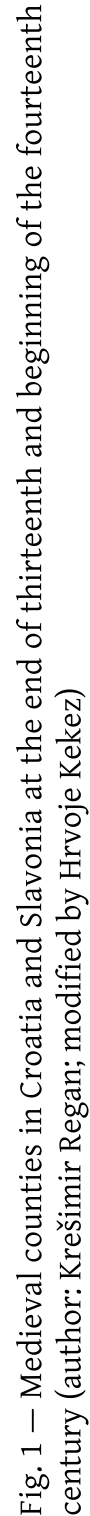




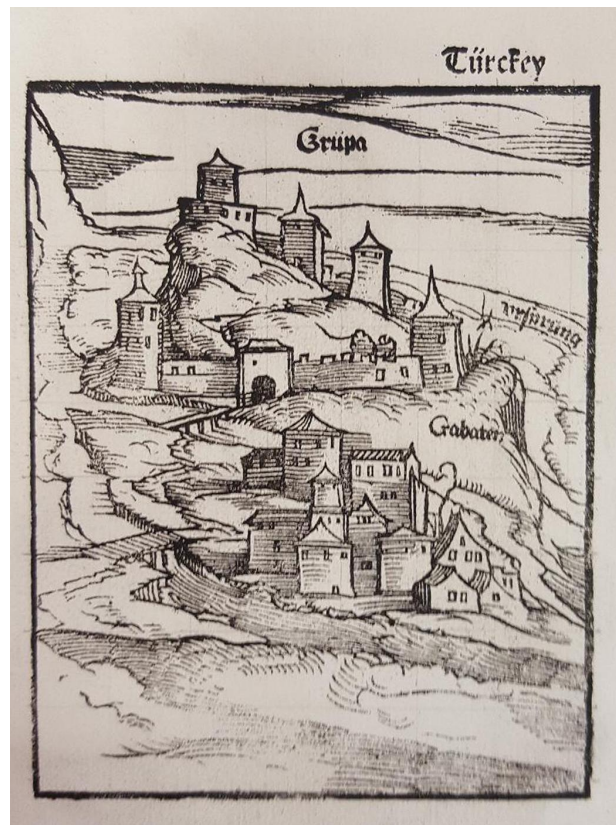

Fig. 2 - Krupa - castle and marketplace in 1530 (source: Slike iz putopisa B. Kuripešičeva u Carigrad od godine 1531, ed. Ivan Standl, Agram: Druck der Typo-litografischen Anstalt des C. Albrecht, 1879, [n. pag.])

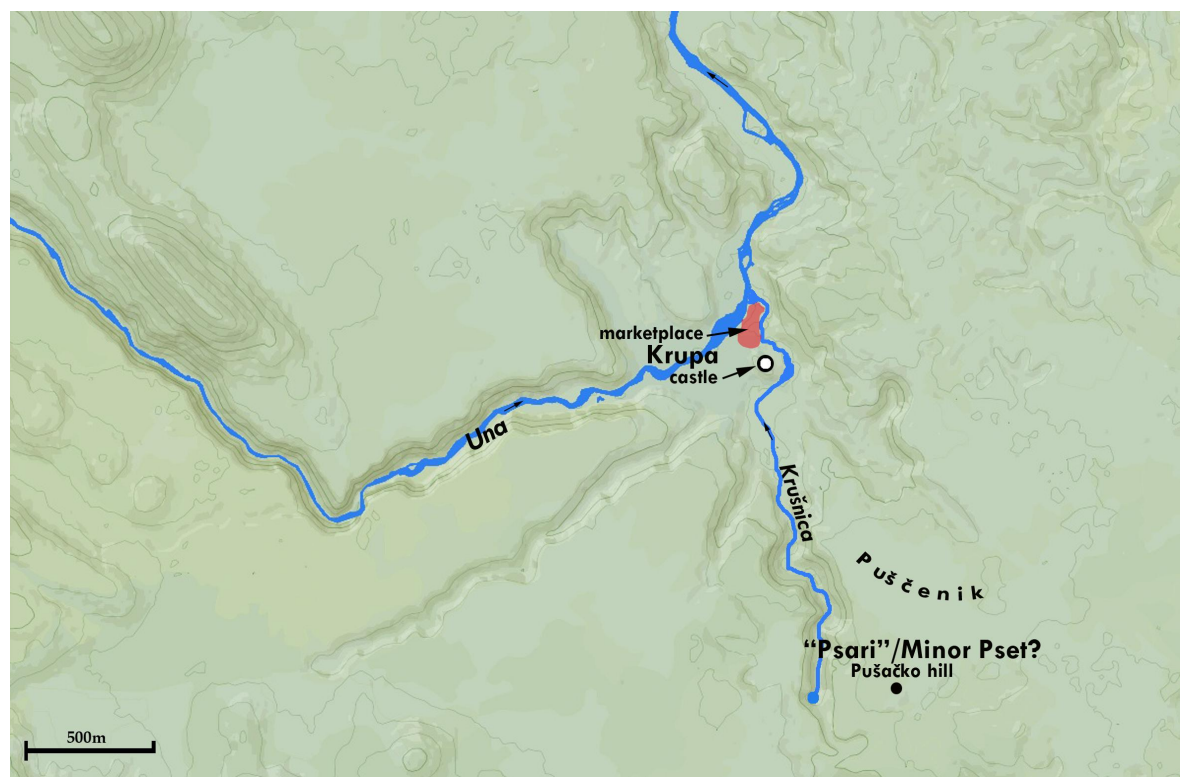

Fig. 3 - Topography of the area of Krupa castle at the beginning of the sixteenth century (author: Hrvoje Kekez) 


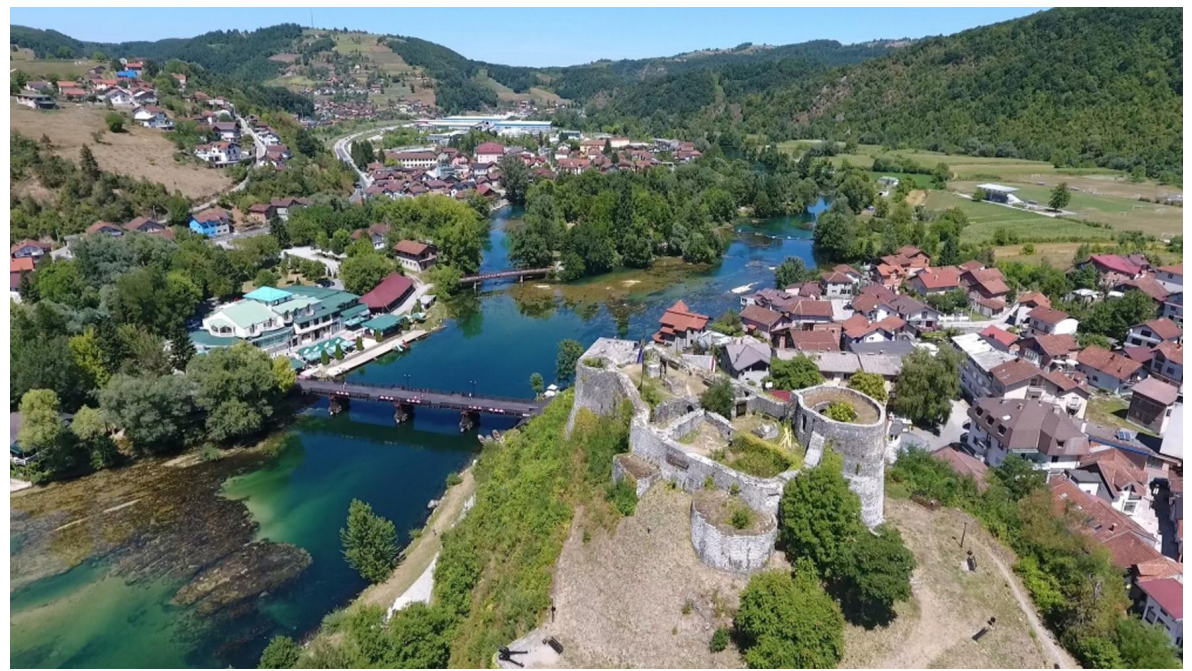

Fig. 4 - Krupa castle today (source: 〈http://www.abc.ba〉, [accessed 17 May 2018])

\section{Summary}

The present article is a fresh attempt at locating 'Psary' castle - the 'ancestral home' of Prince Lech that has been mentioned in numerous legends about the origins of the Poles - through a reinvestigation of the geographical information provided by two chroniclers: Jan Długosz and Maciej of Miechów. After analysing extant medieval sources from the historical lands of Croatia, as well as Croatian historiography, it is possible to dismiss the identification of 'Psary' castle with either Krapina or Pharos (Starigrad on the island of Hvar). Both chroniclers (Jan Długosz and Maciej of Miechów) clearly stated that the legendary stronghold of 'Psary' castle was situated on the border of Croatia and Slavonia. While Krapina was located on the border of medieval slavonia and Steierrmark, Pharos was situated on the Adriatic island of Hvar in medieval Dalmatia, a considerable distance away from the then border of Croatia or Slavonia. The author would like to offer a new interpretation of the geographical information given by these two renaissance authors. Namely, Długosz's river 'Huy' can be identified as the present-day River Una, and Miechów's River 'Krupa' as the Krušnica stream in the vicinity of contemporary Bosanska Krupa. Finally, the author accepts the premise present in Croatian historiography, in accordance with which 'Psary' was the stronghold of Minor Pset (Lesser Pest), the political and economic centre of the medieval Croatian county of Pset, however he dismisses as unlikely the idea that Minor Pset ('Psary') was one and the same with the late medieval castle of Krupa, which was an assumption accepted by most Croatian historians. Following an analysis of Miechów's sources, medieval Croatian records and current Croatian historiography, the author argues that 
they point to two locations situated in close proximity to each other. The first of these was the medieval castle of Krupa, which dates to the beginning of fourteenth century, while the other, the castle of Minor Pset ('Psary'), is older and was located most probably on Pušačko Hill (Pušačko brdo), near the late medieval castle of Krupa.

(Proofreading by Maciej Zakrzewski)

\section{Bibliography}

Analecta ad historiam renascentium in Hungaria litterarum spectantia, ed. Eugenius Abel, Budapest: Academia Scientiarum Hungaricæ; Leipzig: Brockhaus, 1880.

The Annals of Jan Długosz: Annales seu cronicce incliti regni Polonice, ed. Maurice Michael, Charlton: IM Publications, 1997.

Bali, Tomislav, Slavonski meandar: Prostor i pojam Slavonije u XIII. stoljeću, Zagreb: Srednja Europa, 2014.

Bene, Sándor, 'Ideološke koncepcije o staleškoj državi zagrebačkoga kanonika', in Juraj Rattkay, Spomen na kraljeve i banove Kraljevstva Dalmacije, Hrvatske i Slavonije, transl. Zrinka Blažević et al., Zagreb: Hrvatski institut za povijest, 2001, pp. 4-103.

Beuc, Ivan, Povijest institucija državne vlasti kraljevine Hrvatske, Slavonije i Dalmacije, Zagreb: Pravni fakultet - Centar za stručno usavršavanje i suradnju s udruženim radom, 1985.

Brather, Sebastian, 'Ethnische Identitäten als Konstrukte der frühgeschichtlichen Archäologie', Germania, 78, 2000, pp. 139-77.

Codex diplomaticus Regni Croatioe, Dalmatice et Slavonice, 18 vols, ed. Tade Smičiklas, Zagreb: Jugoslavenska akademija znanosti i umjetnosti, 1904-90, vol. 2, 1904, vol. 4, 1906, vol. 5, 1907, vol. 6, 1908, vol. 9, 1911.

Čoralić, Lovorka, Put, putnici i putovanja: Ceste i putovi u srednjovjekovnim hrvatskim zemljama, Zagreb: AGM, 1997.

Cromerius, Martinus, De origine et rebus gestis Polonorum libri XXX, Basel: per Ioannem Oporinum, 1555.

Curipeschitz, Benedict, Itinerarium der Botschaftsreise des Josef von Lamberg und Niclas Jurischitz durch Bosnien, Serbien, Bulgarien nach Konstantinopel, 1530, ed. Eleonore Lamberg-Schwarzenberg, Innsbruck: Wagner'schen Universitäts-Buchhandlung, 1910.

Gaj, Ljudevit, Die Schlösser bei Krapina, Karlovac: Prettner, 1826.

Grgin, Borislav, 'Županije u razvijenom i kasnom srednjem vijeku', in Hrvatske županije kroz stoljeća, ed. Ivo Goldstein, Zagreb: Školska knjiga, 1996, pp. 21-38.

Ioannes de Dąbrówka, Commentum in Chronicam Polonorum magistri Vincentii dicti Kadłubek, ed. Marian Zwiercan, Cracow: Polska Akademia Umiejętności, 2008, Monumenta Poloniæ Historica, Series nova, vol. 14.

Ioannis Dlugossi Annales seu Cronicae incliti Regni Polonice. Liber 1/2, ed. Wanda Semkowicz-Zaremba, Warsaw: Państwowe Wydawnictwo Naukowe, 1964. 
Kekez, Hrvoje, Pod znamenjem propetog lava: Povijest knezova Babonića do kraja 14. stoljeća, Zagreb: Hrvatski institut za povijest, 2016.

Klaić, Nada, Izvori za hrvatsku povijest do 1526. godine, Zagreb: Školska knjiga, 1972.

Klaić, Nada, Povijest Hrvata u razvijenom srednjem vijeku, Zagreb: Školska knjiga, 1976.

Klaić, Vjekoslav, 'Županija Pset (Pesenta) i pleme Kolunić', Vjesnik Hrvatskog arheološkog društva NS, vol. 15, 1928, pp. 1-12.

Kos, Milko, 'Odnošaji medju goričkim grofovima i hrvatskim plemstvom u srednjem vijeku', Vjesnik Zemaljskog arhiva, 19, 1917, pp. 208-303.

Kreševljaković, Hamdija, Stari bosanski gradovi, Sarajevo: Zemaljski zavod za zaštitu spomenika kulture i prirodnih rijetkosti NR Bosne i Hercegovine, 1953.

Kruhek, Milan, Drežnik Grad: Srednjovjekovno naselje i kaštel Frankopana na Korani, Rakovica: Općina Rakovica, 2009.

Kruhek, Milan, ‘Topografija krbavske spomeničke baštine’, in Krbavska bitka i njezine posljedice, ed. Dragutin Pavličević, Zagreb: Hrvatska matica iseljenika, 1997, pp. 99-129.

Lopašić, Radoslav, Bihać i Bihaćka Krajina: Mjestopisne i poviestne crtice, Zagreb: Matica hrvatska, 1890.

Magistri Vincentii dicti Kadłubek Chronica Polonorum, ed. Marian Plezia, Cracow: Polska Akademia Umiejętności, 1994, Monumenta Poloniæ Historica, Series nova, vol. 11.

Małecki, Aleksander, "Croatian "Psary" Versus Dalmatian "Pharos" in the Legendary Begginnigs of Poland', Sensus Historiae, 10, 2013, p. 9-20.

Mathias de Miechow, Tractatus de duabus Sarmatijs Asiana: \& Europiana \& de contentis in eis, Cracow: Impressum opera et impensis Joannes Haller, 1517.

Mažuran, Ive, Hrvati i Osmansko Carstvo, Zagreb: Golden marketing, 1998.

Miletić, Drago ‘Istraživanja, konzervatorsko-restauratorski radovi i idejni projekti prezentacije s prijedlozima nove namjene staroga grada u Hrvatskoj Kostajnici', in Hrvatska Kostajnica: 1240.-2000., ed. Marija Krupić, Hrvatska Kostajnica: Grad Hrvatska Kostajnica; Zagreb: Hrvatski institut za povijest, 2002, pp. 285-314.

Rattkay, Juraj, Spomen na kraljeve i banove Kraljevstva Dalmacije, Hrvatske i Slavonije, transl. Zrinka Blažević et al., Zagreb: Hrvatski institut za povijest, 2001.

Šišić, Ferdo, Povijest Hrvata u vrijeme narodnih vladara, Zagreb: Školska knjiga, 1925.

Slike iz putopisa B. Kuripešičeva u Carigrad od godine 1531, ed. Ivan Standl, Agram: Druck der Typo-litografischen Anstalt des C. Albrecht, 1879.

Smičiklas, Tadija, Radoslav Lopašić: Nekrolog, Zagreb: Jugoslavenska akademija znanosti i umjetnosti, 1895.

Smith, Anthony D., The Ethnic Origins of Nations, Oxford: Blackwell, 1986.

Spomenici Hrvatske krajine, 3 vols, ed. Radoslav Lopašić, Zagreb: Jugoslavenska akademija znanosti i umjetnosti, 1884-89.

Temelji moderne Hrvatske: Hrvatske zemlje u 'dugom' 19. stoljeću, ed. Vlasta Švoger and Jasna Turkalj, Zagreb: Matica hrvatska, 2016. 
Truhelka, Ćiro, Naši gradovi: Opis najljepših sredovječnih gradova Bosna i Hercegovine, Sarajevo: Naklada knjižare J. Studnička i dr., 1904.

Verholantsev, Julia, The Slavic Letters of St. Jerome: The History of the Legend and its

Legacy, or, How the Translator of the Vulgate Became an Apostle of the Slavs, DeKalb: Northern Illinois University Press, 2014.

Biog r a phy: Hrvoje Kekez - Associate Professor of Medieval History at the Department of History of the Catholic University of Croatia in Zagreb. His scholarly interests include the history of the medieval Croatian and Slavonian nobility, medieval urbanism, medieval and renaissance narratives, and the Croatian heraldic heritage.E-mail: hrvoje.kekez@unicath.hr. 